\title{
KEPEMIMIPINAN EFEKTIF KEPALA SEKOLAH \\ DALAM PENGEMBANGAN BUDAYA MUTU DI SMP NEGERI 21 PURWOREJO
}

\author{
Suryani Umroniyah \\ (SMP N 25 Purworejo) \\ suryani0627@gmail.com
}

\begin{abstract}
ABSTRAK
Kepala sekolah berfungsi sebagai leader dan manajer di sekolah yang memiliki peran penting dalam mewujudkan visi misi sekolah. Oleh karena itu Kepala sekolah dituntut mampu mengelola lembaga yang dipimpinnya. Penelitian ini bertujuan mendiskripsikan kepemimpinan efektif kepala sekolah di SMPN 21 Purworejo yang mencakup perannya dalam membentuk visi, menciptakan iklim ramah, membina kepemimpinan, meningkatkan pembelajaran, dan mengelola sumber daya manusia, data dan proses dalam rangka pengembangan budaya mutu sekolah. Penelitian ini merupakan penelitian kualitatif. Pengumpulan data dilakukan terhadap sumber-sumber penelitian dengan menggunakan teknik wawancara, observasi, serta dokumentasi. Data yang terkumpul diolah dengan kegiatan reduksi data, penyajian data, dan penarikan kesimpulan. Uji keabsahan data dilakukan dengan teknik triangulasi untuk menjamin bahwa data yang didapatkan adalah valid. Hasil penelitian ini menunjukkan bahwa kepemimpinan kepala sekolah efektif dalam mengembangkan budaya mutu di SMP Negeri 21 Purworejo dilakukan melalui pembentukan visi yang mencakup perumusan visi secara bersama warga sekolah, komitmen terhadap visi,misi, dan tujuan sekolah, kemampuan memelihara visi yang kuat, serta menciptakan iklim pembelajaran yang kondusif. Menciptakan iklim ramah mencakup penyediaan fasilitas sekolah yang aman, nyaman serta ramah terhadap lingkungan, menciptakan iklim yang ramah bagi peserta didik dan staf, iklim ramah yang melampaui tembok sekolah. Membina kepemimpinan pada orang lain mencakup memberi kepercayaan pada bawahan, membangun tim kerja yang efektif, serta mendelegasikan sebagian wewenangnya pada orang lain. Meningkatkan pembelajaran mencakup evaluasi terhadap program pembelajaran, penciptaan strategi peningkatan pembelajaran, berkolaborasi dalam pembelajaran, penggunaan metode yang interaktif, inspiratif dan menyenangkan, teknik supervisi, dan peningkatan profesi tenaga pendidikan. Mengelola sumber daya manusia mencakup penempatan guru dan staf sesuai keahliannya, mendukung peningkatan profesi guru dan staf, memanfaatkan potensi guru dan staf, serta bersikap hati-hati dan mengedepankan tauladan;; mengelola data mencakup pemanfaatan data sebagai rujukan membuat keputusan, penyimpanan data secara tepat, serta pemanfaatan data untuk penyelidikan kolaboratif; mengelola proses mencakup menseleksi penerimaan peserta didik maupun pegawai baru, serta mentoring terhadap pegawai baru.
\end{abstract}

Kata Kunci: Kepemimpinan Efektif, Kepala Sekolah, Budaya Mutu. 


\section{PENDAHULUAN}

Kegiatan manusia secara bersama-sama selalu membutuhkan kepemimpinan. Jadi harus ada pemimpin demi sukses dan efisiensi kerja. Oleh karena itu, banyak studi dan penelitian dilakukan orang untuk mempelajari masalah pemimpin dan kepemimpinan. Dalam suatu organisasi kepemimpinan seseorang mutlak diperlukan, karena pemimpin merupakan panutan, teladan bagi anggotanya untuk mencapai tujuan yang diharapkan. Kompri menyatakan bahwa pemimpin menjadi barometer keberhasilan suatu organisasi atau kelompok dalam proses perencanaan, pelaksanaan, pemberian motivasi, pengawasan sehingga tercapainya tujuan-tujuan bersama dalam kelompok tersebut. ${ }^{1}$

Dalam suatu organisasi, pelaksanaan tugas-tugas oleh bawahan terpengaruhi oleh kepemimpinan seorang pemimpin. Kepemimpinan yang lemah dapat dipastikan menghambat dalam operasional kegiatan, dan sebaliknya kepemimpinan yang kuat mendorong prestasi bawahan serta kegiatan dalam pencapaian tujuan. Kepemimpinan yang baik harus bisa menciptakan iklim yang kondusif demi tercapainya tujuan bersama dalam suatu organisasi. Dengan demikian, kepemimpinan yang baik dapat meningkatkan kemampuan bawahan.

Mereka bisa menunjukkan kualitas kerja secara maksimal, sehingga pencapaian tujuan dapat dilakukan secara efektif dan efisien. Menurut Kaswan, pemimpin yang efektif adalah pemimpin yang memiliki dampak positif bagi organisasi dan komunitas di sekelilingnya. ${ }^{2}$ Beberapa indikator yang dapat kita pakai sebagai petunjuk keberhasilan kepemimpinan dalam suatu organisasi yaitu: (1) Meningkatnya hasil-hasil produksi dan pemberian pelayanan oleh organisasi. (2) Semakin rapinya sistem administrasi dan makin efektifnya manajemen. (3) Semakin meningkatnya aktivitasaktivitas manusia atau aspek sosial yang lebih human sifatnya. ${ }^{3}$ Jadi kepemimpinan merupakan salah satu faktor yang sangat penting dalam suatu organisasi karena sebagian besar keberhasilan dan kegagalan suatu organisasi ditentukan oleh kepemimpinan dalam organisasi tersebut.

\footnotetext{
${ }^{1}$ Kompri. Manajemen dan Kepemimpinan Pondok Pesantren, (Jakarta: Prenadamedia Group, 2018), hlm. 170.

${ }^{2}$ Kaswan. Kepemimpinan Dampak Dan Warisannya; Praktek Kepemimpinan Untuk Meraih Keunggulan Organisasi Jangka Pendek Dan Jangka Panjang.(Jakarta: Bumi Aksara, 2019), hlm.7.

${ }^{3}$ Kartini \& Kartono. Pemimpin dan Kepemimpinan Apakah Kepemimpinan Abnormal Itu?, (Jakarta: Raja Grafindo Persada, 2016), hlm.229.
} 
Untuk mewujudkan seseorang menjadi pemimpin yang ideal dibutuhkan syaratsyarat yang tergambarkan dalam bentuk ciri-ciri yang dimiliki. Adapun ciri-ciri untuk menjadi seorang pemimpin adalah: (1) Memiliki kompetensi yang sesuai dengan zamannya, (2) Memahami setiap permasalahan secara lebih dalam dibandingkan dengan orang lain, (3) Mampu menerapkan konsep "the right man and the right place" secara tepat dan baik. ${ }^{4}$ Seorang pemimpin dalam mengarahkan bawahannya tidak hanya dilakukan atas dasar perintah semata, namun seorang pimpinan harus mengedepankan sikap kewibawaan yang teraplikasi dalam bentuk personal power yang dimiliki. Personal power atau kekuatan pribadi itu tidak lahir begitu saja, namun melalui berbagai proses yang panjang. Dalam arti tidak mungkin seorang pemimpin bisa bertindak bijaksana jika ia tidak merasakan apa yang sesungguhnya dialami oleh bawahannya tersebut. Seorang pimpinan lebih dihormati, ditaati serta dikagumi karena karakter baiknya, bukan karena jabatan yang disandangnya. Bagi seorang pemimpin, jabatan adalah amanah. Budi pekerti serta karakter adalah cerminan jiwa yang terpancar dalam sikap, tindak, dan tanduk. Dalam suatu kepemimpinan peran utama pemimpin adalah usaha mempengaruhi orang lain agar secara suka rela mau mengikuti apa yang dikehendaki untuk mencapai tujuan yang telah ditetapkan. Sebagaimana yang diungkapkan Badeni, menyatakan bahwa: kepemimpinan adalah suatu proses mempengaruhi orang lain agar berperilaku sesuai dengan yang diinginkan pemimpin tanpa ada rasa terpaksa dari si pengikut untuk mencapai tujuan tertentu. ${ }^{5}$

Dalam lingkup pendidikan, sekolah adalah pihak yang terkait dalam urusan pendidikan. Sekolah menjadi suatu organisasi yang dirancang untuk dapat memberikan kontribusi dalam upaya peningkatan kualitas hidup masyarakat luas. Sekolah adalah suatu lembaga dimana seorang peserta didik menuntut ilmu secara formal dan merupakan wadah bagi para peserta didik dalam menentukan arah atau langkah yang ingin ditempuh serta untuk menentukan cita-cita yang ingin mereka capai untuk masa depannya. Pendidikan memiliki peran yang sangat penting dalam membangun sumber daya manusia. Untuk itu, dibutuhkan sistem pendidikan yang mampu menghasilkan manusia seutuhnya, yaitu sitem pendidikan yang memandang bahwa mutu merupakan

\footnotetext{
${ }^{4}$ Irham Fahmi. Manajemen Kepemimpinan Teori \& Aplikasi, (Bandung: Alfabeta, 2014), hlm.19.

${ }^{5}$ Badeni. Kepemimpinan dan Perilaku Organisasi, (Bandung: Alfabeta, 2014), hlm.128.
} 
salah satu tujuannya. Sekolah sebagai bagian dari sebuah organisasi, peran kepemimpinan di lingkungan sekolah menjadi sangat penting.

Kepala sekolah pada dasarnya guru yang diberi tugas tambahan sebagai kepala sekolah. Dia pemimpin tertinggi operasional sebuah sekolah. Sebagai pemegang kekuasaan tertinggi dan memiliki kewenangan di tingkat sekolah perlu memahami dengan baik tentang kepemimpinan kepala sekolah.

Kepala sekolah sebagai pejabat fungsional dan profesional bertugas untuk mengatur semua sumber daya sekolah serta mendayagunakannya dengan melibatkan guru-guru, staf, serta pegawai lainnya yang ada di sekolah dalam rangka membimbing dan mendidik peserta didik untuk mengoptimalkan potensinya sesuai dengan tujuan pendidikan. Kepala sekolah yang profesional akan mengetahui kebutuhan sekolah, mempunyai kemampuan untuk memimpin dan memberdayakan segala sumber daya yang ada di suatu sekolah secara maksimal untuk mencapai tujuan bersama. Mulyasa menyatakan bahwa kepala sekolah merupakan salah satu komponen pendidikan yang paling berperan dalam meningkatkan kualitas pendidikan. ${ }^{6}$ Untuk mencapai terwujudnya peningkatan kualitas pendidikan, seorang kepala sekolah hendaknya bekerja secara profesional. Untuk meraih gelar profesional, ada beberapa komponen (kemampuan spesifik) yang harus dimiliki oleh seorang kepala sekolah. Di samping memiliki 5 (lima) komponen, seseorang bisa disebut sebagai kepala sekolah yang profesional jika mampu menjalankan perannya sebagai edukator, manajer, administrator, supervisor, leader/pemimpin, inovator dan motivator.

Pendidikan dan pengalaman yang dimiliki kepala sekolah merupakan faktor yang mempengaruhi kepemimpinannya. ${ }^{7}$ Dengan modal pendidikan yang dimiliki serta waktu yang dapat dipakai oleh kepala sekolah untuk menjalankan fungsi kepemimpinannya, merupakan faktor-faktor yang sangat mempengaruhi kesempatan kepala sekolah untuk mengembangkan kepemimpinannya. Kepala sekolah bertanggung jawab terhadap perkembangan sekolah yang dipimpinnya. Kepala sekolah bertanggung jawab penuh terhadap seluruh aspek operasional penyelenggaraan sekolah, mulai dari perencanaan, pengorganisasian, pelaksanaan, sampai pada kepengawasan. Aan

\footnotetext{
${ }^{6}$ Mulyasa. Menjadi Kepala Sekolah Profesional, (Bandung: Remaja Rosdakarya, 2011), hlm.24.

${ }^{7}$ Agustinus Hermina. Pemimpin Pendidikan Di Era Globalisasi, (Yogyakarta: Pustaka Pelajar, 2014), hlm. 127.
} 
Komariah menyatakan bahwa: Kepala sekolah dalam menjalankan tanggung jawabnya hendaknya memahami peranannya sebagai seorang pemimpin pendidikan. ${ }^{8}$

Sebagai seorang leader atau pemimpin di suatu instansi pendidikan, kepala sekolah seharusnya memiliki sifat, karakter yang kuat, visi dan misi yang jelas, profesionalisme yang tinggi dalam bekerja, ide, gagasan yang kreatif untuk memajukan sekolahnya. Kepala sekolah sebagai motor penggerak di sekolah harus mampu dan mau bekerja keras, mempunyai dorongan kerja yang tinggi, tekun dan tabah dalam bekerja, memberikan layanan yang optimal, dan disiplin yang kuat. Supaya bisa melaksanakan amanah kepemimpinannya dengan baik, tentunya dengan menyerap aspirasi yang masuk. Aspirasi yang masuk disaring, dikerucutkan mana yang bersifat mendukung terwujudnya kemajuan sekolah.

Kepala sekolah mempunyai peran yang sangat penting dalam mempengaruhi, menggerakkan seluruh sumber daya yang ada di sekolah. Peran kepemimpinan pendidikan adalah kegiatan mempengaruhi pengikut dalam rangka mengembangkan dan memajukan sekolah. ${ }^{9}$ Kepemimpinan seorang kepala sekolah mencakup cara-cara dan usahanya dalam mempengaruhi, memberikan dorongan, bimbingan, serta menggerakkan guru, staf, siswa dan orang tua siswa demi tercapainya tujuan sekolah. ${ }^{10}$

Keberhasilan pendidikan di sekolah sangat ditentukan oleh kepala sekolah dalam mengelola sumber daya yang ada di sekolah. Husaini Usman menyatakan bahwa kepala sekolah merupakan manajer yang mengorganisir seluruh sumber daya sekolah dengan menggunakan prinsip “TEAMWORK," yaitu rasa kebersamaan (together), pandai merasakan (empathy), saling membantu (assist), saling penuh kedewasaan (maturity), saling mematuhi (willingness), saling teratur (organization), saling menghormati (respect), dan saling berbaik hati (kindness). ${ }^{11}$

Berbicara tentang sekolah, pada dasarnya kita berbicara tentang warga sekolah. Sekolah adalah sebuah institusi sosial tempat terjalinnya interaksi dan relasi antara kepala sekolah, guru, murid, administrator, penjaga sekolah, petugas kebersihan

\footnotetext{
${ }^{8}$ Aan Komariah \& Cepi Triana. Visionary Leadership, Menuju Sekolah efektif, (Jakarta: Bumi Aksara, 2008), hlm.123.

${ }^{9}$ Wuradji. The Educational Leadership, Kepemimpinan Transformasional, (Yogyakarta: Gama Media, 2008), hlm.95.

${ }^{10}$ Dadang Dally. Balanced Score Card Suatu pendekatan dalam Implementasi Manajemen Berbasis Sekolah, (Bandung: Remaja Rosdakarya, 2010), hlm.28.

${ }^{11}$ Husaini Usman. Manajemen, Teori, Praktik, Dan Riset Pendidikan, (Jakarta: Sinar Grafika Offset, 2008), hlm.49.
} 
sekolah, orang tua, komite sekolah, dan semua yang terlibat dalam suatu penyelenggaraan sekolah. Masing-masing aktor tersebut tidak ada yang boleh merasa lebih berjasa dan terhormat di antara satu sama lain. Kepala sekolah dengan seluruh warga sekolah bersama-sama memiliki kepahaman tentang bagaimana menciptakan iklim pembelajaran yang kondusif. Jika hal tersebut tidak terjadi, upaya pencapaian visi, misi dan tujuan akan menemui banyak kendala, banyak memendam persoalan, kehilangan dukungan dari masyarakat, tidak dipercaya dan yang paling mengerikan adalah buruknya hasil belajar anak yang dapat menghambat harapan masa depan bangsa untuk meraih cita-cita.

Kepala sekolah merupakan salah satu komponen pendidikan yang paling berperan dalam meningkatkan mutu pendidikan. Seperti diungkapkan Supriadi, bahwa: erat hubungannya antara mutu sekolah dengan berbagai aspek kehidupan sekolah seperti disiplin sekolah, iklim budaya sekolah, dan menurunnya perilaku nakal peserta didik. ${ }^{12}$

Merujuk pada pendapat di atas, dalam dunia nyata perkembangan ilmu pengetahuan, teknologi, seni dan budaya yang diterapkan dalam pendidikan di sekolah cenderung bergerak maju dan semakin pesat, sehingga kepala sekolah di tuntut untuk melaksanakan pengembangan pendidikan secara terarah, terencana, dan berkesinambunagn untuk meningkatkan kualitas pendidikan.

Di antara sejumlah peran kepemimpinan kepala sekolah di suatu sekolah adalah membangun dan menumbuh kembangkan budaya mutu sekolah. Kepala sekolah bersama guru, administrator sekolah, murit, dan orang tua diharapkan memiliki wawasan bagaimana menciptakan budaya sekolah yang positif, yang didasari nilai dan keyakinan bersama demi terciptanya lingkungan sekolah yang kondusif. Menciptakan budaya sekolah positif akan tertanamnya karakter dan moral yang baik pada siswa dan juga warga sekolah.

Dalam sekolah, setiap orang memiliki tugas dan kewajiban yang berbeda satu sama lain. Namun demikian, perbedaan tersebut mesti diikat dalam suatu nilai-nilai yang dapat mendorong ke arah pencapaian yang positif. Masing-masing warga sekolah harus didorong untuk memastikan bahwa seluruh tindakannya sesuai dengan harapan sekolah yang punya nilai-nilai budaya. Berkaitan dengan budaya sekolah Adi Kurnia dan Bambang Qomaruzzaman menyatakan bahwa hal yang tampak atau tidak tampak,

${ }^{12}$ Mulyasa, 2011, Op.Cit. 
formal maupun informal, pada dasarnya berkontribusi pada bagaimana warga sekolah, guru, murid, kepala sekolah, administrator, petugas kebersihan, petugas keamanan, orang tua, dan masyarakat membentuk dan memperkuat budaya yang positif. ${ }^{13}$

Kepala sekolah, sebagai motor penggerak peningkatan kualitas pendidikan di sekolah, perlu memahami cara-cara pembentukan dan pengelolaan budaya sekolah. ${ }^{14}$ Salah satu upaya yang dapat ditempuh adalah dengan merevitalisasi budaya sekolah yang bersumber pada nilai-nilai manajemen berbasis sekolah, etos kerja, dan integritas seluruh elemen sekolah. Budaya sekolah diharapkan mampu memberikan kontribusi secara maksimal terhadap upaya peningkatan mutu pendidikan.

Budaya organisasi, termasuk di dalamnya budaya sekolah, merupakan variabel kunci yang bisa mendorong keberhasilan suatu organisasi. ${ }^{15}$ Hal tersebut dibuktikan oleh adanya sejarah pertumbuhan peradaban manusia. Salah satu faktor penentu keberhasilan dan keberlangsungan sebuah organisasi adalah kuat tidaknya peran kepemimpinan dalam menciptakan budaya organisasi. Pada akhirnya budaya organisasi tersebut akan menentukan kualitas kinerja dan produktivitas.

Budaya sekolah berkorelasi dengan prestasi belajar siswa, peningkatan motivasi dan kepuasan produktivitas kerja guru. ${ }^{16}$ Efek langsung dari sekolah yang telah menerapkan budaya sekolah yang kuat adalah: (1) etos kerja warga sekolah meningkat, (2) iklim kerja lebih kondusif, akrab, dan stabil, (3) partisipasi warga sekolah dalam kegiatan peningkatan mutu pendidikan tinggi dan menyeluruh, (4) kepuasan kerja guru dan siswa lebih tinggi, dan (5) pada akhirnya produktivitas berupa mutu pendidikan meningkat tajam.

Salah satu konsep peningkatan mutu adalah teori effektive school yang lebih memfokuskan pada perbaikan proses pendidikan. ${ }^{17}$ Beberapa indikator yang menunjukkkan karakter dari konsep peningkatan mutu antara lain sebagai berikut: (1) lingkungan sekolah yang aman dan tertib, (2) sekolah memiliki misi dan target mutu yang ingin dicapai, (3) sekolah memiliki kepemimpinan yang kuat, (4) adanya harapan

\footnotetext{
${ }^{13}$ Adi Kurnia \& Bambang Qomaruzzaman. Membangun Budaya Sekolah, (Bandung: Remaja Rosdakarya Offset, 2012), hlm.23.

${ }^{14}$ Aan Komariah \& Cepi Triatna, Op.Cit, hlm.113.

${ }^{15}$ Achmad Sobirin. Budaya Organisasi, (Yogyakarta: STIM YKPN, 2010), hlm.244.

${ }^{16}$ Stolp S. Leadership For School Culture, Eric Digest: Number 91. (New Jearsey: McGrawHill, 1994), hlm.13.

${ }^{17}$ Edmonds. Effective School, (Oklahoma, 1999), hlm.12.
} 
yang tinggi dari personel sekolah untuk berprestasi, (5) adanya pengembangan staf sekolah sesuai dengan tuntutan perkembangan ilmu dan teknologi, (6) adanya pelaksanaan evaluasi yang kontinyu dan dimanfaatkan sebagai penyempurnaan/perbaikan mutu, dan (7) adanya komunikasi dan dukungan intensif dari orang tua murid/masyarakat.

Hampir semua pakar sekolah efektif mengekslisitkan kepemimpinan sebagai ciri penting sekolah efektif. ${ }^{18}$ Indikator kepemimpinan sekolah efektif antara lain mampu menetapkan tujuan masa depan sekolah secara profesional. Nilai, kepercayaan, sikap, dan perilaku (merupakan komponen esensial dari budaya sekolah) merupakan dasar bagi setiap kepemimpinan sekolah dalam menyusun dan melaksanakan program pengembangan sekolah.

Sadeghi \& Pihie mengemukakan bahwa: "Effeective leaders can lead organizations to success by paying more attention to environmenta! Changes, which in turn helps them set proper goals and objectives." Pemimpin yang efektif dapat memimpin organisasi untuk sukses dengan lebih memperhatikan perubahan lingkungan, yang pada gilirannya membantu mereka menetapkan objek dan tujuan yang tepat. ${ }^{19}$

Agar dapat memimpin lembaga pendidikan secara efektif seorang kepala sekolah harus memiliki kompetensi. Dari beberapa kompetensi yang harus dimiliki salah satunya adalah kompetensi mengembangkan budaya sekolah. Kompetensi kepala sekolah dalam mengembangkan budaya sekolah, sebagaiman dikatakan oleh Mulyono:

1. Menerapkan dan mengembangkan nilai-nilai kehidupan sekolah yang demokratis.

2. Membentuk budaya kerja sama (school corporate cultur) yang kuat.

3. Menumbuhkan budaya profesionalisme warga sekolah.

4. Menciptakan iklim sekolah yang kondusif-akademis.

5. Menumbuhkembangkan keragaman budaya dalam kehidupan sekolah.

6. Mengembangkan budaya kewirausahaan sekolah. ${ }^{20}$

Pengembangan budaya dalam suatu sekolah perlu ditunjang oleh perubahan berbagai aspek pendidikan lainnya, termasuk iklim sekolah. Perubahan iklim sekolah perlu dilakukan untuk merespon kondisi pendidikan saat ini yang penuh dengan

\footnotetext{
${ }^{18}$ Ibid, hlm.23.

${ }^{19}$ Eliyanto. Manajemen \& Kepemimpinan Pendidikan Islam, (Kebumen: Institut Agama Islam Nahdlatul Ulama (IAINU) Kebumen, 2018), hlm.41.

${ }^{20}$ Mulyono. Manajemen Administrasi \& Organisasi Pendidikan, (Jogjakarta: Ar-Ruzz Media, 2008), hlm. 160 .
} 
tantangan. Hal ini lebih diperkuat lagi dengan perubahan-perubahan mendasar dalam berbagai aspek kehidupan, yang menuntut penyesuaian pendidikan, dan iklim sekolah yang kondusif yang menunjang terhadap pembelajaran yang bermutu. Dalam kerangka inilah perlunya kepemimpinan kepala sekolah dalam menciptakan iklim dan budaya mutu sekolah yang kondusif, untuk mencapai tujuan pendidikan yang diharapkan.

Kepemimpinan kepala sekolah harus kuat dan berkualitas sesuai dengan perkembangan zaman. Kepala sekolah juga dituntut memiliki kemampuan dan ketrampilan kepemimpinan agar tujuan dan program yang telah dibina dapat tercapai secara efektif, sehingga dapat meningkatkan mutu pendidikan. Meningkat tidaknya mutu sekolah tergantung pada kebijaksanaan kepala sekolah yang diterapkan terhadap semua warga sekolah.

Kepala sekolah mempunyai peranan yang sangat penting dalam membangun budaya mutu di sekolah, untuk membentuk karakter lembaga sebagai identitas yang dapat membedakan dengan lembaga yang lain, maka kepala sekolah sebagai pemimpin dituntut untuk mengembangkan budaya mutu sekolah yang ada.

Budaya mutu adalah sebuah sistem makna bersama yang dianut oleh para anggota yang membedakan suatu organisasi dari organisasi lainnya. Sistem makna bersama ini adalah sekumpulan karakteristik kunci yang dijunjung tinggi oleh organisasi. ${ }^{21}$ Budaya mutu sekolah merupakan perpaduan nilai-nilai, keyakinan, asumsi, pemahaman, dan harapan yang diyakini oleh warga sekolah serta dijadikan pedoman bagi perilaku dan pemecahan masalah internal dan eksternal yang mereka hadapi. ${ }^{22}$

Terbentuknya budaya mutu tidak lepas dari dua faktor yaitu internal dan eksternal. Faktor internal adalah nilai-nilai yang sudah tertanam dalam diri manusia yang terpancar pada keseluruhan gerak-gerik dan kebiasaan, tata cara, gagasan, dan nilai-nilai yang dipelajari dan diwariskan serta perilaku yang ditimbulkannya atau artifacts. Sedangkan faktor eksternal adalah adanya faktor-faktor lain seperti pengaruh

\footnotetext{
21 Stephen P. Robbins. Organizational Behavior. (San Diego State University: Person Education International, 2003), pg. 13.

22 Ida Ayu Brahmasari \& Agus Suprayitno. Pengaruh Motivasi Kerja, Kepemimpinan dan Budaya Organisasi Terhadap Kepuasan Kerja Karyawan Serta Dampaknya Pada Kinerja Perusahaan Jurnal Manajemen dan Kewirausahaan, Vol.10. No.2, Hlm. 127. Surabaya: Pascasarjana Universitas 17 Agustus 2008.
} 
kepemimpinan, lingkungan, sehingga merubah nilai-nilai yang tertanam di dalamnya karena ada dorongan dari eksternal atau agent of change. ${ }^{23}$

Manfaat budaya mutu sebagai berikut: (1) budaya mutu menciptakan perbedaan yang jelas antara satu budaya mutu sekolah dengan budaya mutu sekolah lain, (2) budaya mutu membawa satu rasa identitas bagi anggota-anggota sekolah, (3) budaya mutu mempermudah timbulnya komitmen pada sesuatu yang lebih luas dari kepentingan-kepentingan individu, (4) budaya mutu meningkatkan kemantapan sisten sosial. $^{24}$

Edgar H. Schein menyatakan bahwa, ada tiga tingkatan budaya mutu yaitu: pertama; artifacts, adalah suatu yang dimodifikasi oleh manusia untuk tujuan tertentu, artifacts dapat dilihat dari struktur sebuah organisasi dan proses dilakukan di dalamnya Espoused Values, adalah nilai-nilai yang didukung, terdiri dari strategi, tujuan, dan filosofi organisasi. Tingkat ini mempunyai arti penting dalam kepemimpinan, nilai-nilai ini harus ditanamkan pada tiap-tiap anggota organisasi. Underlying Assumption, adalah asumsi yang mendasari yaitu suatu keyakinan yang dianggap sudah harus ada dalam diri tiap-tiap anggota mengenai organisasi yang meliputi aspek keyakinan, pemikiran dan keterikatan perasaan terhadap organisasi. ${ }^{25}$

Budaya yang kuat adalah sebuah kunci kesuksesan sebuah budaya mutu, karena budaya mutu mengandung nilai-nilai yang harus dipahami, dijiwai, dan dipraktekkan bersama oleh semua individu atau kelompok yang terlibat didalamnya. Kepala sekolah sebagai pemimpin harus mampu menerjemahkan nilai-nilai budaya mutu ke dalam lingkungan internal dan eksternal terutama bagi anggotanya. Proses perubahan ini akan sukses apabila pemimpin mampu melakukan perubahan secara terencana sehingga semua anggota mendaptkan seluas-luasnya untuk beradaptasi terhadap perubahan

Budaya mutu sebagai perangkat lunak harus kompertible dengan perangkat kerasnya, perlunya kompertible ini menunjukkan bahwa budaya mutu tidak bisa berdiri sendiri. Budaya mutu berfungsi sebagai alat untuk mendiskripsikan dan menjelaskan

\footnotetext{
${ }^{23}$ Stephen P. Robbins, Op.Cit. pg.3.

${ }^{24}$ Mardiyah. Kepemimpinan Kiai Dalam Memelihara Budaya Organisasi, (Tlogomas, Malang: Aditya Media Publishing, 2013), hlm.8.

${ }^{25} \mathrm{Ibid}, \mathrm{hlm} .9$.
} 
apa yang terjadi dalam sekolah untuk memahami budaya mutu yang lebih baik dan utuh. $^{26}$

Implikasi dari pembentukan nilai budaya mutu adalah terbentuknya karakter lembaga atau sekolah yang merupakan identitas mutu diri sekolah sehingga menghasilkan outcame sekolah yang berkualitas serta memiliki keunggulan mutu tersendiri. Dengan demikian, jika sekolah dikelola dengan baik oleh kepala sekolah selaku pemimpin, maka budaya mutu sebagai identitas diri dan bisa menjadi andalan integrasi diri untuk keberhasilan mutu sekolah.

Berpedoman dari uraian di atas dan memperhatikan realita selama ini bahwa banyak pihak menjelaskan mutu sekolah hanya dilihat dari dimensi yang tampak, yang bisa dikuantifikasikan terutama perolehan nilai UAN murni dan kondisifisik sekolah tersebut. Padahal perolehan nilai UAN murni dan kondisi fisik sekolah bukanlah satusatunya indikator sebuah sekolah tersebut bermutu atau tidak, akan tetapi adanya nilainilai yang ditanamkan kepala sekolah dan guru kepada peserta didik sehingga menjadi nilai-nilai luhur yaitu budaya mutu sebagai pondasi keberhasilan sekolah.

Penulis merasa tertarik untuk melakukan penelitian di SMP Negeri 21 Purworejo karena berdasarkan pengamatan penulis, 9 tahun sepeninggal penulis mutasi dari sekolah tersebut ke sekolah yang baru, semakin lama semakin baik mutu sekolahnya. walaupun letak sekolah tersebut berada di desa, paling jauh dari pusat kota Purworejo, namun mutunya sangat menggembirakan. Berdasarkan data yang diambil selama 2 tahun terakhir, pencapaian prestasi akademik pada ujian Nasional mengalami kenaikan peringkat, dari tahun sebelumnya. Informasi yang diperoleh dari waka kurikulum, dari sejumlah SMP yang ada di kabupaten Purworejo, tahun ajaran 2016/2017 untuk sekolah negeri sebanyak 43 sekolah, SMP Negeri 21 Purworejo menduduki peringkat 15, sedangkan untuk sekolah negeri dan swasta yang ada di Purworejo sebanyak 105 sekolah, SMP Negeri 21 Purworejo menduduki peringkat 18. Pada tahun ajaran 2017/ 2018 untuk sekolah negeri berada pada peringkat 11, dan untuk sekolah negeri dan swasta sama yaitu berada pada peringkat 11 kabupaten.. Jika ditinjau dari prestasi ujian nasional peringkatnya mengalami kenaikan yang cukup drastis, naik 7 peringkat dari tahun sebelumnya, ini menunjukkan bahwa sekolah tersebut memiliki kemauan untuk mengembangkan mutu sekolahnya. Kalau dilihat dari animo masyarakat untuk masuk

\footnotetext{
${ }^{26}$ Ida Ayu Brahmasari \& Agus Suprayitno, Op.Cit, hlm.128.
} 
ke SMP Negeri 21 Purworejo, ternyata animo masyarakat cukup tinggi, sehingga tidak semua pendaftar bisa diterima, mengingat kursi yang tersedia hanyalah 160 siswa (5 Rombel). Dilihat dari tingginya animo masyarakat untuk masuk ke SMP Negeri 21 Purworejo, menandakan jika sekolah tersebut memiliki mutu yang bagus, karena menjadi rujukan orang tua untuk mempercayakan pendidikan bagi anaknya kepada sekolah tersebut. Disamping itu Tatan Sutrisna selaku kepala sekolah pada tahun 2018 berhasil menyabet juara 3 lomba kepala sekolah berprestasi tingkat kabupaten Purworejo. Prestasi tersebut sebagai gambaran kalau ia seorang kepala sekolah yang berkualitas. Oleh karena itu penulis ingin mengetahui bagaimana kepemimpinan kepala sekolah yang diterapkan di SMP Negeri 21 Purworejo dalam mengembangkan budaya mutu di sekolah yang dipimpinnya, nilai-nilai atau budaya apa saja yang ditanamkan pada sekolah tersebut, sehingga bisa mengantarkan mutu sekolahnya semakin baik.

Hal itulah yang menjadi dasar pemikiran bagi peneliti sehingga perlu untuk diadakan penelitian dengan judul "Kepemimpinan Efektif Kepala Sekolah Dalam Pengembangan Budaya Mutu Di SMP Negeri 21 Purworejo. Hal tersebut untuk mengetahui dan menganalisis tentang: (1) implementasi kepala sekolah dalam membentuk visi dalam rangka pengembangan budaya mutu di SMP Negeri 21 Purworejo. (2) implementasi kepala sekolah dalam menciptakan iklim ramah terhadap pendidikan dalam rangka pengembangan budaya mutu di SMP Negeri 21 Purworejo. (3) implementasi kepala sekolah dalam membina kepemimpinan pada orang lain dalam rangka pengembangan budaya mutu di SMP Negeri 21 Purworejo. (4) implementasi kepala sekolah dalam meningkatkan pembelajaran dalam rangka pengembangan budaya mutu di SMP Negeri 21 Purworejo. (4) implementasi kepala sekolah dalam mengelola sumber daya manusia, data, dan proses untuk membantu perbaikan sekolah dalam rangka pengembangan budaya mutu di SMP Negeri 21 Purworejo.

\section{KAJIAN LITERATUR}

\section{Kepemimpinan Efektif Kepala Sekolah}

Kepala sekolah merupakan motor penggerak, penentu kebijakan sekolah yang akan menentukan bagaimana tujuan sekolah dan pendidikan pada umumnya direalisasikan. Kepala sekolah dituntut untuk senantiasa meningkatkan efektifitas kinerjanya. Kinerja kepemimpinan kepala sekolah yang efektif adalah segala upaya 
yang dilakukan dengan hasil yang dapat dicapai mewujudkan tujuan pendidikan secara efektif dan efisien.

Orang yang berkecimpung dalam dunia pendidikan perlu memahami tentang pentingnya kepemimpinan kepala sekolah sebagai pemimpin pendidikan tingkat sekolah yang memiliki peran penting dalam mewujudkan sekolah efektif, dan pembelajaran yang berkualitas. Sekolah yang baik tentu saja dipimpin oleh kepala sekolah yang baik. Ada kepala sekolah efektif pasti ada sekolah efektif.

Menurut Wallin, empat dimensi kepemimpinan sekolah efektif yaitu: (a) menetapkan arah (visi, misi, dan tujuan) serta bekerjasama dengan seluruh stakeholder, seperti orang tua, siswa, dan guru; (b) mengembangkan dan meningkatkan prestasi belajar siswa; (c) memilih dan menetapkan personil sekolah serta mengevaluasi kinerja mereka; dan (d) membuat program untuk pengembangan professional diri mereka sendiri. $^{27}$

Syarat kepemimpinan kepala sekolah yang efektif meliputi: (a) kepala sekolah harus komitmen terhadap visi, misi, dan tujuan sekolah; (b) menjadikan visi sebagai pedoman dalam mengelola sekolah; (c) menciptakan budaya dan iklim yang kondusif; dan (d) mengoptimalkan segala komponen pendidikan (guru, siswa, orang tua, komite sekolah, kurikulum, dan sarana prasarana) untuk senantiasa fokus pada kegiatan akademik (pembelajaran). ${ }^{28}$

Kesimpulannya kepala sekolah efektif harus mengetahui: (a) pendidikan yang baik diperlukan di sekolah; (b) sesuatu diperlukan untuk meningkatkan mutu sekolah; (c) tata cara mengelola sekolah untuk mencapai prestasi baik. Kemampuan untuk menguasai ketiga hal tersebut dapat dijadikan standar kelayakan apakah seseorang dapat menjadi kepala sekolah efektif atau tidak.

Dalam kepemimpinan kepala sekolah secara efektif kerja tim sangat penting karena kepala sekolah tidak akan mampu memecahkan masalah dengan baik sendirian. John S. Oakland menulis, "Kerja tim dalam sebuah organisasi merupakan komponen penting dari implementasi manajemen mutu terpadu (MMT), mengingat kerja tim akan meningkatkan kepercayaan diri, komunikasi, dan mengembangkan kemandirian." 29

\footnotetext{
${ }^{27}$ Eliyanto, Op.Cit, hlm.42.

${ }^{28}$ Ibid.

${ }^{29}$ Edward Sallis. Total Quality Management In Education, Terjemah Ahmad Ali Riadi \& Fahrurozi, (Yogyakarta: Ircisod, 1993), hlm.90.
} 
Sepuluh kunci kesuksesan kepala sekolah yang efektif, efisien, produktif dan akuntabel mencakup: (a) visi yang utuh, (b) tanggung jawab, (c) keteladanan, (d) memberdayakan staf, (e) mendengarkan orang lain, (f) memberikan layanan prima, (g) mengembangkan orang, (h) memberdayakan sekolah, (i) fokus pada peserta didik, (j) Manajemen yang mengutamakan praktik. ${ }^{30}$

Seorang kepala sekolah yang efektif berkaitan dengan layanan kepada warga sekolah, akan memberikan layanan yang bermutu, layanan yang baik atau layanan prima (excellence service). Hal ini sangat penting dalam dunia pendidikan, supaya peserta didik nyaman berada di sekolah dan bisa melakukan pembelajaran secara optimal.

Kepemimpinan yang efektif dimulai dengan pengembangan visi dan komitmen di seluruh sekolah terhadap standar tinggi dan keberhasilan semua siswa. Kepala sekolah membantu untuk menguraikan visi itu dan membuat semua yang lain mendukungnya. ${ }^{31}$

Kepala sekolah dikatakan efektif manakala telah menciptakan iklim pembelajaran yang baik atau mengambil tindakan pembelajaran yang baik dan telah mampu memelihara visi yang kuat yang dapat dipelajari oleh semua siswa. Mereka memiliki visi dan percaya bahwa semua siswa dapat mencapai pada tingkat yang tinggi. Selanjutnya, menetapkan standar tinggi dan tujuan yang tepat dan ketat untuk setiap siswa adalah bagian penting dari pekerjaan pemimpin sekolah yang efektif. ${ }^{32}$

Pengoordinasian organisasi sekolah merupakan wewenang dari kepala sekolah. Untuk itu kecakapan kepala sekolah mutlak diperlukan. Kepala sekolah perlu memahami peranannya dengan baik, sehingga mampu menjalankan tugas-tugasnya sebagai seorang kepala sekolah. Terlebih seorang kepala sekolah yang efektif yang pada dirinya melekat suatu pengharapan yang tinggi terhadap prestasi seluruh siswanya, peran kepemimpinannya sangat diharapkan berbuah peningkatan mutu pada sekolah yang dipimpinnya.

Menurut Made Pidarta, lima posisi atau peran pokok kepemimpinan kepala sekolah, antara lain kepala sekolah sebagai manajer, administrator, motor humas,

\footnotetext{
${ }^{30}$ Mulyasa. Manajemen Dan Kepemimpinan Kepala Sekolah, (Jakarta: Bumi Aksara, 2015), hlm.23-45.

${ }^{31}$ Mendels, P. The effective principal. Journal of Staff Development, Vol 33, No.1, 2012, Pg. 54-58.

${ }^{32}$ Spiro, J.D. Effective principals in action. Principal's Research Review, Vol.10, No.1, 2015, Pg.1-6.
} 
pemimpin dan superfisor. ${ }^{33}$ Kepala sekolah yang demikianlah yang akan mampu mendorong visi menjadi aksi dalam mewujudkan sekolah yang bermutu.

\section{Budaya Mutu Sekolah}

Budaya sekolah adalah sebuah kumpulan nilai-nilai, sikap, kepercayaan, dan norma-norma yang dijunjung tinggi bersama oleh warga sekolah, baik secara implisit maupun eksplisit. ${ }^{34}$ Budaya sekolah juga dikatakan sebagai sekumpulan norma, nilai, dan tradisi yang telah dibangun dalam waktu yang lama oleh semua warga sekolah dan mengarah ke seluruh aktivitas personal sekolah. ${ }^{35}$

Budaya sekolah merupakan jaringan kompleks dari berbagai interaksi aktor dalam sekolah yang dimanifestasikan dalam tradisi dan ritual yang dibangun di antara guru, murit, orang tua, administrator untuk menghadapi berbagai tantangan dalam mencapai tujuan. ${ }^{36}$ Adapun secara khusus budaya sekolah adalah pola nilai-nilai, norma-norma, sikap, ritual, mitos, dan kebiasaan-kebiasaan yang dibentuk dalam perjalanan panjang sekolah. $^{37}$

Terbentuknya budaya sekolah dipengaruhi oleh banyak faktor. Adapun faktorfaktor yang mempengaruhi terbentuknya budaya sekolah menurut Kompri adalah "antusias guru dalam mengajar dan penguasaan materi dengan segala model pembelajaran, patuh pada aturan, berdisiplin tinggi, sikap guru terhadap siswa, dan gaya kepemimpinan kepala sekolah. ${ }^{38}$

Kepala sekolah sebagai figur sentral harus menyadari bahwa terbentuknya kebiasaan, sikap, dan perilaku dalam konteks budaya sekolah sangat dipengaruhi oleh pribadi, gaya kepemimpinan, dan cara dia melihat perkembangan ke depan yang bersifat visioner. $^{39}$

Aspek budaya ternyata memiliki peran yang cukup penting dalam pencapaian mutu berkelanjutan. Pengertian budaya mutu sebagaimana yang diungkapkan oleh

\footnotetext{
${ }^{33}$ Eliyanto, Op.Cit, hlm.39.

${ }^{34}$ Ibid, hlm.71.

${ }^{35}$ Daryanto. Supervisi Pembelajaran, (Yogyakarta: Gava Media, 2015), hlm.6.

${ }^{36}$ Adi Kurnia \& Bambang Qomaruzzaman, Op.Cit, hlm.24.

${ }^{37}$ Nurkolis. Manajemen Berbasis Sekolah Teori, Model dan Aplikasi, (Jakarta: Grasindo, 2006), hlm.203.

${ }^{38}$ Kompri. Manajemen Sekolah Teori dan Praktik, (Bandung: Alfabeta, 2014), hlm.263.

${ }^{39} \mathrm{lbid}$.
} 
Ikawijaya yaitu: Budaya mutu terdiri dari filosofi, keyakinan, sikap, norma, tradisi, prosedur, dan harapan yang meningkatkan kualitas. ${ }^{40}$

Menurut Goetsch D.L. \& Davis D.L., budaya mutu adalah sistem nilai organisasi yang menghasilkan suatu lingkungan yang kondusif bagi pembentukan dan perbaikan mutu secara terus-menerus. ${ }^{41}$ Budaya mutu adalah sebuah sitem makna bersama yang dianut oleh para anggota yang membedakan suatu sekolah dari sekolah lainnya. Sistem makna bersama ini adalah sekumpulan karakteristik kunci yang dijunjung tinggi oleh sekolah.

Dalam konteks pengembangan sekolah atau mutu sekolah, memahami makna budaya dalam kehidupan sekolah dianggap sangat relevan. Oleh karena itu budaya bisa dianggap sebagai aset. Paling tidak budaya berperan sebagai alat untuk melakukan integrasi internal. ${ }^{42}$ Jika peran ini bisa berfungsi dengan baik dan dibarengi oleh penyusunan strategi yang tepat maka bisa diharapkan kinerja sekolah akan meningkat.

Budaya mutu lebih baik dipahami berdasarkan pengamatan terhadap perilaku dan kebiasaan-kebiasaan yang dilakukan oleh para anggota sekolah. ${ }^{43}$ Budaya mutu hendaknya terpatri pada sanubari semua warga sekolah sehingga setiap tindakan didasari oleh profesionalisme. Dengan demikian sekolah harus kreatif dan dinamis dalam usaha pengembangan mutu sekolah supaya bisa memuaskan pelanggan. Maka dari itu perlunya budaya mutu dalam suatu sekolah.

\section{METODE PENELITIAN}

Jenis penelitian ini yaitu kualitatif pendekatan deskriptif, pendekatan yang lebih menekankan pada aspek pemahaman secara mendalam terhadap suatu masalah manusia dan sosial. Waktu penelitian adalah antara bulan Februari s/d April 2019. Tempat penelitian adalah di SMP Negeri 21 Purworejo, yang berada di Desa Brunorejo Kec. Bruno Kab. Purworejo Prov. Jawa Tengah.

\footnotetext{
${ }^{40}$ Sudarwan Danim. Visi Baru Manajemen Sekolah Dari Unit Birokrasi ke Lembaga Akademik, (Jakarta: Bumi Aksara, 2015), hlm.56.

${ }^{41}$ Nanang Fattah. Sistem Penjaminan Mutu Pendidikan Dalam Konteks Penerapan MBS, (Bandung: Remaja Rosdakarya, 2017), hlm.22.

${ }^{42}$ Paine Lyn.S. Managing For Organizational Integrity, (Harvard Busines Review, 1994), pg. 115.

${ }^{43}$ Achmad Sobirin, Op.Cit, hlm.51.
} 
Subjek penelitian ini yaitu peneliti/penulis sendiri. Sedangkan responden penelitian ini yaitu kepala sekolah, wakil kepala sekolah, guru, dan pegawai tata usaha beserta karyawan, komite sekolah, dan siswa-siswi SMP Negeri 21 Purworejo.

Teknik pengumpulan data merupakan cara yang digunakan peneliti untuk memperoleh data penelitian yang dibutuhkan. Proses pengumpulan data dalam penelitian ini dilakukan dengan: observasi, wawancara mendalam, dan dokumentasi.

Dalam menguji keabsahan data peneliti menggunakan tehnik Triangulasi, yakni teknik pemeriksaan keabsahan data yang memanfaatkan sesuatu yang lain diluar data untuk keperluan pengecekan atau sebagai pembanding terhadap data itu.Itu artinya melakukan validasi, dengan cara mengecek dokumen program dan bukti tertulis lainnya. ${ }^{44}$ Dalam penelitian ini menggunakan Triangulasi metode yaitu menggunakan dua strategi yaitu: (1) Pengecekan terhadap derajat kepercayaan penemuan hasil penelitian dengan beberapa tehnik pengumpulan data; (2) Pengecekan derajat kepercayaan beberapa sumber data dengan metode yang sama.

Langkah-langkah yang dilakukan penulis lakukan untuk menganalisis data yang sudah diperoleh dari hasil observasi, wawancara, dan dokumentasi yaitu dengan menggunakan model analisis data Miles dan Huberman sebagaimana yang dikutip oleh Sugiyono, yaitu reduksi data (data reduction), penyajian data (data display), dan penarikan kesimpulan (conclusion drawing/verification). ${ }^{45}$

\section{HASIL PENELITIAN DAN PEMBAHASAN}

Pembahasan data penelitian ini merupakan pengkajian atau penelaahan terhadap hasil penelitian tentang kepemimpinan efektif kepala sekolah dalam pengembangan budaya mutu di SMP Negeri 21 Purworejo. Selengkapnya pembahasan data penelitian tersebut dapat dipaparkan sebagai berikut:

\section{Kepala Sekolah yang Efektif Membentuk Visi dalam Rangka Pengembangan Budaya Mutu di SMP Negeri 21 Purworejo}

Seorang kepala sekolah yang baik harus memiliki visi yang jelas, ke arah mana tujuan akan dicapai, bagaimana usaha yang perlu dilakukan untuk mencapai tujuan tersebut. Kepemimpinan kepala sekolah diharapkan dapat menterjemahkan visi misi ke

\footnotetext{
${ }^{44}$ Michael Quinn Patton. Metode Evaluasi Kualitatif. (Yogyakarta: Pustaka Pelajar, 2006), hal. 280

${ }^{45}$ Sugiyono, Metode Penelitian Pendidikan, (Bandung: Alfabeta. 2009), hal. 254
} 
dalam bentuk kegiatan sekolah yang bisa menuju ke arah tercapainya pendidikan yang bermutu. Perilaku kepala sekolah yang baik dapat mendorong warga sekolah untuk bekerja sama dalam mewujudkan visi dan misi sekolah.

Visi yang menjadi pusat perhatian kepemimpinan kepala sekolah efektif merupakan mimpi-mimpi indah yang akan diwujudkan di masa mendatang sehingga visi mengandung harapan pencapaian prestasi yang diharapkan. Visi mengandung berbagai macam cita-cita ke depan. Lembaga-lembaga pendidikan mulai dari pendidikan rendah tingkat Taman Kanak-kanak hingga Perguruan Tinggi rata-rata memiliki visi. Namun demikian, banyak pimpinan lembaga pendidikan maupun warga sekolah yang tidak menyadari bahwa visi yang telah dirumuskan tidak ditindaklanjuti melalui misi yang konkret. Sebaik apapun sebuah rumusan visi suatu sekolah, apabila tidak ditindaklanjuti melalui misi yang konkret maka hanyalah sia-sia belaka. Dengan demikian perlu difahami bahwa visi itu penting sekali bagi sebuah lembaga pendidikan, dikembangkan menjadi misi yang kemudian diwujudkan dalam program-program yang telah dibuat untuk menuju tercapainya tujuan pendidikan yang diharapkan.

Visi menjadi semangat untuk merealisasikan harapan tercapainya prestasi pendidikan, menumbuhkn kegairahan dalam melangkah, menjadi pedoman di dalam bertindak. Visi seharusnya mendapat perhatian yang besar bagi pemimpin-pemimpin lembaga pendidikan. Mereka dituntut mampu merumuskan visi yang mampu menumbuhkan pemberdayaan di kalangan warganya. Visi yang bisa menumbuhkan kesadaran bagi setiap warga sekolah untuk komitmen dengan visi yang telah dibuat, bekerja sekuat tenaga mengejar terwujudnya sekolah yang bermutu.

Visi memiliki tujuan paling utama dalam mengawal tercapainya kemajuan sebuah lembaga pendidikan. Visi yang baik bisa dikembangkan menjadi misi-misi yang kemudian diwujudkan dalam program-program sekolah, disiapkan fasilitas-fasilitas yang dibutuhkan, dikondisikan lingkungan yang menunjang, ditanggulangi ancamanancaman yang menghadang, diterapkan dalam serangkaian kegiatan.

Kepala sekolah yang baik dalam melaksanakan tugasnya memahami betul visi tentang sekolahnya. Baginya visi merupakan daya pandang yang jauh ke depan, memiliki kekuatan yang dapat mempengaruhi seluruh staf. Visi sekolah harus menjadi atribut kepemimpinan kepala sekolah sekarang dan di masa yang akan datang, karena kepala sekolah dengan visi yang tidak jelas bisa menjadikan kemunduran bagi sekolah 
yang dipimpinnya, bernasib tidak baik, bahkan mungkin akan mengalami keterpurukan yang kemudian ditinggalkan oleh pelanggannya.

Di sinilah pentingnya kepala sekolah memiliki dan memahami visi yang utuh tentang sekolahnya, agar dapat membawa sekolahnya ke arah kemajuan dan kemandirian. Hal-hal yang harus dilakukan kepala sekolah dalam hal visi sekolah adalah:

\section{a. Merumuskan, Mensosialisasikan dan Meninjau Kembali Rumusan Visi Misi}

Dalam perannya sebagai seorang pimpinan, Tatan Sutrisna selaku kepala sekolah SMPN 21 Purworejo telah berhasil merumuskan visi dan misi berdasarkan masukan dari berbagai kalangan yang ada di sekolah. Kepala sekolah bertindak secara demokratis kepada warganya dengan memberikan kesempatan untuk berpartisipasi dalam perumusan visi misi sekolah.

Sebagai tindak lanjut perumusan visi misi, tampak kemampuan kepala SMPN 21 Purworejo dalam melakukan sosialisasi tentang visi dan misi kepada warga sekolah dan pihak-pihak pemangku kepentingan. Sosialisasi dilakukan baik secara lesan maupun tulisan.

Visi misi yang sudah dirumuskan tidak dipakai untuk selamanya, tetapi bilamana sudah tidak sesuai lagi, dilakukan peninjauan kembali untuk disesuaikan dengan perkembangan sekolah.

\section{b. Komitmen Terhadap Visi, Misi dan Tujuan Sekolah}

Komitmen terhadap visi misi dan tujuan sekolah maksudnya kemampuan kepala sekolah beserta staf dalam mewujudkan program dan kegiatan sekolah sesuai dengan visi sekolah. Implementasi visi merupakan kemampuan kepala sekolah dalam menjabarkan dan menterjemahkan visi ke dalam tindakan. Seluruh warga sekolah untuk komitmen menjadikan visi sebagai pedoman dalam mencapai tujuan sekolah.

\section{c. Kemampuan Memelihara Visi yang Kuat dalam Mengelola Sekolah}

Untuk mengantarkan sekolahnya menjadi sekolah yang bermutu, seorang kepala sekolah harus bisa memiliki kemampuan memelihara visi yang kuat didalam mengelola sekolah. Kemampuan memelihara visi yang kuat dapat dilihat dari penanaman nilai-nilai atau budaya-budaya sekolah sebagai berikut: (1) Budaya bersih, (2) Budaya baca, (3) Budaya disiplin, (4) Budaya jujur, (5) Budaya religious, (6) Budaya berprestasi. 


\section{d. Menciptakan Iklim Pembelajaran yang Kondusif}

Dalam membangun keefektifan sekolah, kepala sekolah memulainya dari kemampuan menciptakan suasana sekolah yang kodusif yaitu suatu suasana yang bisa mendukung terlaksananya proses belajar dan mengajar dengan baik. Ikbal Barlian mengatakan mengungkapkan bahwa budaya dan iklim kerja yang kondusif akan memungkinkan setiap guru lebih termitivasi untuk menunjukkan kinerjanya secara unggul yang disertai usaha untuk meningkatkan kompetensinya. ${ }^{46}$ Hallinger mengatakan "Dapat dipastikan bahwa ada hubungan antara kepemimpinan dan iklim sekolah, di mana iklim tersebut adalah faktor yang berkaitan dengan efektivitas sekolah." Dengan iklim yang kondusif kepala sekolah bisa memberikan rasa aman, nyaman, dan menguntungkan guru, siswa dan staf administrasi. ${ }^{47}$

Proses pembelajaran berkaitan erat dengan kondisi psikologis anak ketika berada di lingkungan mereka belajar, baik di kelas maupun di lingkungan sekolah serta rumah. Lingkungan yang kondusif dan mendukung proses belajar peserta didik harus menjadi pertimbangan kepala sekolah dan para guru serta pihak terkait. Ketika kondisi lingkungan sekolah serta lingkungan masyarakatnya dapat memberikan rasa nyaman untuk belajar, peserta didik bisa vokus dalam belajar, maka hampir dapat dipastikan bahwa hasil belajar mereka akan memuaskan dan menjadi lebih bermutu.

Demikian halnya yang terjadi di SMP Negeri 21 Purworejo, Tatan Sutrisna telah mampu menciptakan iklim kerja yang kondusif, sehat, nyaman, dan menggembirakan. Suasana kerja di lingkungan SMP Negeri 21 Purworejo berjalan penuh kekeluargaan, harmonis dan sejuk. Hubungan kepala sekolah dengan guru dan para karyawan baik dalam kedinasan, kemitraan (kolegial) dan kekeluargaan sangat harmonis. Iklim kerja yang terbangun diwarnai dengan penuh persaudaraann saling asah asih dan asuh, kesetaraan tanpa membeda-bedakan kedudukan. Kepala sekolah memposisikan dirinya dengan guru dan karyawan sebagai teman bukan menonjolkan sebagai atasan dengan bawahan. Hubungan kepala sekolah dengan semua warga sekolah mulai dari guru, karyawan-karyawati, tukang kebun/penjaga sekolah, siswa akrab.

\footnotetext{
${ }^{46}$ Ikbal Barlian. Manajemen Berbasis Sekolah Menuju Sekolah Berprestasi, (Jakarta: Erlangga, 2013), hlm.71.

${ }^{47}$ Hallinger. Reassessing The Principal's Role In School Effectiveness: A Review Of Empirical Research, 1980-1995. Educational Administration Quarterly, Vol.32 No.1, 1996, Pg. 5-44.
} 
Untuk menciptakan iklim kelas yang kondusif, dengan cara berkeliling kelas, mengecek keadaan kelas-kelas apakah terkondisikan dengan baik apa tidak. Di samping itu, untuk menciptakan suasana pembelajaran yang kondusif, kepala SMP Neger 21 Purworejo juga menegakkan tata tertib sekolah, baik itu tata tertib siswa, maupun tata tertib guru karyawan.

\section{Kepala Sekolah yang Efektif Menciptakan Iklim Ramah terhadap Pendidikan dalam Rangka Pengembangan Budaya Mutu di SMP Negeri 21 Purworejo}

Kepala sekolah sebagai pemimpin pendidikan pada tingkat sekolah memiliki peranan yang cukup besar dalam mengembangkan mutu pendidikan di sekolah yang menjadi tanggung jawabnya. Tumbuh kembangnya semangat kerja para guru dan karyawan, tumbuhnya semangat belajar para siswa tergantung pada kinerja kepala sekolah, komunikasi antar pribadi kepala sekolah, serta kemampuannya dalam menciptakan lingkungan sekolah yang ramah terhadap anak, ramah antar semua warga sekolah, serta ramah kepada semua tamu dari luar, yang menjadi salah satu modal tercapainya mutu pendidikan. Kalau suasana kerja dan belajar penuh keramahan, semua orang merasa saling dihargai dan diperhatikan, kerja dan belajarpun menjadi semangat. Dengan meningkatnya semangat diharapkan meningkatnya mutu pendidikan.

SMP Negeri 21 Purworejo mempunyai fasilitas yang ramah terhadap anak, memiliki hubungan baik secara internal, yang ditunjukkan oleh adanya hubungan baik antara orang yang terlibat dalam lingkungan sekolah yaitu antara siswa dengan siswa, antara siswa dengan guru, antara guru dengan guru, bahkan antara guru dengan pimpinan sekolah. SMP Negeri 21 secara eksternal berhasil menjalin hubungan baik dengan orang tua siswa, dengan komite sekolah, dengan keluarga besar guru karywan dan lain sebagainya. Dengan tersedianya fasilitas yang ramah terhadap anak, terbangunnya hubungan harmonis/ramah, baik secara internal maupun eksternal yang ditunjukkan oleh kerja sama, saling menghargai, dan saling membantu, maka memungkinkan ilklim belajar menjadi sejuk dan tenang sehingga akan berdampak pada motivasi belajar siswa. Sebaliknya manakala hubungan tidak harmonis/tidak menunjukkan keramahan, iklim belajar akan penuh dengan ketegangan dan ketidak nyamanan sehingga akan mempengaruhi psikologis siswa dalam belajar. 


\section{a. Menyediakan Fasilitas Sekolah yang Aman dan Nyaman serta Ramah terhadap Lingkungan}

Dalam menciptakan lingkungan pendidikan yang memenuhi standar mutu, Tatan Sutrisna sebagai pemimpin sekolah yang efektif menyediakan fasilitas sekolah yang aman, dan nyaman, serta ramah terhadap lingkungan. Fasilitas gedung terlihat kokoh dan kuat, tidak rapuh, menandakan bahwa konstruksinya kuat. Kondisi gedung yang demikian diharapkan bisa menjaga keselamatan anak-anak dari bahaya runtuhnya gedung yang bisa mengancam jiwanya, dengan demikian siswa merasa aman berada di dalamnya. Gedung Nampak terawatt dengan baik, cat tembok kelihatan bersih, membuat para siswa nyaman menempatinya. Untuk menjaga keamanan gedung dari sambaran petir, sekolah melengkapi dengan alat penangkal petir. Di dalam ruang laboratorium IPA yang banyak terdapat zat-zat kimia yang mudah terbakar, sekolah melengkapinya dengan alat pemadam kebakaran rungan (APAR). Dengan terpasangnya alat tersebut anak-anak merasa terjamin keamanannya, ramah terhadap anak. Di samping itu, demi untuk menjaga keselamatan anak dari penyalahgunaan obat-obatan praktikum yang bisa membahayakan jiwanya, semua telah disimpan dengan baik.

Fasilitas lain berkaitan dengan ruangan-ruangan yang ditempati para siswa, aman dari benda-benda yang jatuh baik di dalam maupun di luar. Kondisi eternitnya, papan tulis, pintu, jendela, kursi, meja di setiap ruangan, serta rak-rak buku yang ada di perpustakaan terpasang dengan kuat dan tidak membahayakan. Area bermain yang di sediakan kepala sekolah aman atau ramah terhadap anak. Sekolah menghindari penanaman bunga-bunga yang berduri yang dikhawatirkan bisa membahayakan anak pada saat sedang bermain. Pohon-pohon perindang bebas dari rantig-ranting tua, karena secara berkala di pangkas. Pohon-pohon besar untuk perindang sekolah bilamana ada yang keropos segera ditebang dan diganti dengan penanaman pohon yang baru.

Untuk mengkondisikan bangunan memenuhi persyaratan kesehatan, dilengkapi dengan jendela, krepyak, yang berguna sebagai ventilasi udara, sehingga gedung tidak pengap dan cahaya matahari bisa masuk. Untuk memberikan lingkungan yang ramah bagi anak, terhindar dari berbagai penyakit, sekolah sebagai tempat anak belajar, telah dilengkapi dengan sanitasi baik saluran air bersih, saluran 
air kotor, maupun air hujan, sehingga tidak ada air yang menggenang yang bisa memicu datangnya berbagai penyakit bagi anak. Sampah juga terkelola dengan baik. Sebagai tempat cuci tangan sebagian ruangan dilengkapi dengan wastafel, sedangkan di luar ruangan kelas, terdapat beberapa kran air yang bisa dipakai untuk cuci tangan anak.

Dari serangkaian temuan tentang peran kepemimpinan efektif Tatan Sutrisna, dalam rangka mewujudkan fasilitas sekolah yang ramah terhadap anak, memberikan lingkungan yang bermutu, adalah upayanya untuk memberikan layanan prima terhadap anak. Dengan lingkungan yang berkualitas, aman, nyaman, serta ramah, membantu para anak dalam belajar merasa tenang. Diharapkan anak semakin vokus dalam belajar, konsentrasi tinggi, sehingga akan menghasilkan kualitas pmbelajaran yang baik, pendidikan yang berkualitas.

\section{b. Menciptakan Iklim yang Ramah bagi Peserta Didik dan Staf}

Secara Internal kepala sekolah telah membangun hubungan ramah:

1) Iklim Yang Ramah Kepala Sekolah dan Staf Terhadap Peserta Didik

Upaya penerapan 5S (Senyum, Salam, Salim, Sapa, Santun) kepada para siswa senantiasa terpupuk karena setiap pagi sebelum KBM dimulai kepala sekolah dan beberapa guru melakukan kegiatan yang disebut "Sambut Mentari." Dalam acara sambut mentari kepala sekolah dengan ditemani guru dan staf menunjukkan keramahannya dengan berdiri di depan pintu gerbang menyambut kehadiran para siswa. Budaya ramah juga diterapkan oleh kepala sekolah, guru, dan staf pada saat memberikan pelayanan kepada para siswa baik di dalam kelas, kantor guru atau kantor TU, atau di mana saja. Disamping itu budaya ramah dilakukan oleh kepala sekolah melalui kegiatan MPLS (Masa Pengenalan Lingkungan Sekolah) terhadap para peserta didik baru di awal tahun pelajaran., serta kemah pramuka. Keramahan ini dibangun dalam rangka menanamkan nilainilai luhur, sehingga akan terbentuk karakter yang baik pada diri siswa, membekas sampai siswa menamatkan sekolahnya. Membiasakan siswa untuk ramah kepada siapa saja, tahu hormat kepada guru dan staf, berakhlak mulia, serta menjadi insan yang berkualitas. 


\section{2) Iklim Yang Ramah Sesama Staf}

Suasana keramahan dikembangkan pula pada hubungan guru dengan guru, guru dengan karyawan. Suasana kehidupan keluarga SMP Negeri 21 Purworejo penuh dengan persahabatan, akrab dan menyenangkan. Iklim organisasi yang terbangun di SMP Negeri 21 Purworejo baik, tidak ada kendala sosiologis yang berarti sehingga komunikasi terbangun dengan lancar. Para guru, karyawan senantisa tampil penuh keakraban, hubungan harmonis penuh keramahan.

\section{c. Menciptakan Iklim Ramah yang Melampaui Tembok Sekolah}

Kepala sekolah juga membangun budaya ramah untuk seluruh warga sekolah terhadap para tamu yang berkunjung ke sekolah tersebut. Untuk memupuk keakraban dengan orang-orang yang berada di luar sekolah diadakan beberapa kegiatan seperti: Darma Wanita, wisata keluarga, halal bi halal, rapat pleno sekolah, istighosah, purna widya. Dengan mendapatkan layanan yang ramah dari seluruh warga sekolah, para tamu akan merasa puas atas sambutan terhadap dirinya dan akan membangun sikap positif terhadap sekolah tersebut. Dengan terciptanya iklim ramah ini diharapkan mutu layanan kepada setiap orang akan menjadi semakin baik dan setiap orang merasa diberikan perhatian dan diberikan suasana yang aman dan nyaman, dan terciptanya kepuasan. Dengan terciptanya kepuasan, berarti mutu layanan yang diciptakan kepala SMPN 21 Purworejo tercapai.

\section{Kepala Sekolah yang Efektif Membina Kepemimpinan pada Orang Lain dalam}

\section{Rangka Pengembangan Budaya Mutu di SMP Negeri 21 Purworejo}

Berbagi kepemimpinan adalah hubungan saling mempercayai di mana pemimpin memberikan kesempatan agar stafnya mendapat masukan berkelanjutan dan memberikan fleksibilitas bagaimana tugas-tugas dikerjakan. Sebagai seorang pemimpin sekolah yang efektif, Tatan Sutrisna dalam melaksanakan upaya dan perbaikan mutu sekolah di antaranya memberikan wewenang kepada bawahanya.

Dalam suatu sekolah seorang kepala sekolah tidak akan mampu untuk menjalankan roda kepemimpinan tanpa adanya kolaborasi atau kerjasama dengan stafstaf yang lain. Dengan adanya pelimpahan wewenang, inisiatif dan rasa tanggung jawab para staf dapat lebih terdorong untuk melakukan pekerjaan dengan lebih baik yang pada gilirannya dapat menghasilkan kinerja yang bermutu. Sebagaimana yang terjadi di SMP 
Negeri 21 Purworejo, Tatan Sutrisna selaku kepala sekolah telah berupaya membina kepemimpinan di sekolahnya.

Untuk mengefektifkan pelaksanaan budaya mutu di sekolah, Tatan Sutrisna, S.Pd., MM.Pd. telah membentuk tim kerja sekolah, membentuk struktur organisasi sekolah sebagai wadah pengembangan budaya mutu sekolah. Kepala sekolah menerapkan prinsip partisipasif penuh dalam mengelola organisasi. Beliau berupaya mengoptimalkan peran seluruh sumber daya sekolah yang ada.

\section{a. Kepala Sekolah Memberi Kepercayaan kepada Bawahan}

Kepala sekolah terus membangun kepemimpinan berdasarkan keterbukaan, membangun kepercayaan bawahan untuk ikut dalam pengambilan keputusan. Dalam kepemimpinannya banyak memanfaatkan ide-ide atau gagasan dari bawahan.

\section{b. Kepala Sekolah Membangun Tim Kerja yang Efektif}

Kerja tim sangat penting karena kepala sekolah tidak akan mampu memecahkan masalah-masalah dengan baik secara sendirian. Adanya kerjasama yang kompak komunitas warga sekolah. untuk mengembangkan mutu sekolah telah dibentuk beberapa tim kerja sebagaimana yang dicantumkan dalam bentuk SK. Kepala sekolah dalam menjalankan tugas kepemimpinannya memiliki tim pengembang sekolah yang bertanggung jawab dalam program 8 standar nasional, program peran serta masyarakat dan kemitraan, program budaya dan lingkungan sekolah, program pendidikan budaya dan karakter bangsa; tim pembina OSIS; tim ekstra kurikuler; tim pengayaan intensif kelas IX (les); tim kegiatan pelatihan olimpiade sains nasional (OSN) dan FL2SN, tim petugas guru piket. Kepala SMP Negeri 21 Purworejo dalam mengembangkan budaya mutu di sekolah dengan menciptakan tim work yang keberadaannya menjadi solusi terbaik dalam memajukan sekolah. Adanya kerjasama yang kompak komunitas warga sekolah.

\section{c. Kepala Sekolah Mendelegasikan Sebagian Wewenang kepada Orang Lain}

Kepala sekolah perlu mendelegasikan kepemimpinannya kepada orang lain. Bentuk pendelegasian kepemimpinan yang terjadi di SMP Negeri 21 Purworejo dengan memberdayakan para pemangku kepentingan. Dalam konsep berbagi kepemimpinan, tugas-tugas kepala sekolah diberikan kepada orang lain, sehingga menciptakan para pemimpin selain kepala sekolah. Para pemangku kepentingan di sekolah adalah: 


\section{1) Ketua Komite Sekolah}

Upaya untuk memiliki hubungan baik dengan orang tua/ wali siswa adalah membentuk forum komite sekolah yang bertujuan untuk mencari dukungan ide pendidikan, penggalian sumber dana untuk peningkatan sarana prasarana sekolah demi menunjang mutu pendidikan. Ketua komite sekolah sering berkomunikasi dengan kepala sekolah untuk membicarakan hal-hal yang berkaitan dengan kemajuan SMPN 21 Purworejo.

\section{2) Kepala Tata Usaha}

Kepala tata usaha berfungsi sebagai: a) perencana administrasi program dan anggaran, b) koordinator administrasi ketatausahaan, c) pengelola administrasi program, d) penyusunan laporan program dan anggaran, e) Pembina staf.

Kepala sekolah sebagai administrator sudah bisa menjalankan fungsinya, berhasil mengkondisikan staf TU bekerja sebagaimana mestinya. Administrasiadministrasi sekolah terselesaiakn meskipun belum sepenuhnya.

3) Wakil Kepala Sekolah

Secara umum tugas wakil kepala sekolah adalah: a) Membantu tugas kepala sekolah sesuai dengan tugas bidangnya, b) Mewakili kepala sekolah bila berhalangan.

Kepala sekolah sebagai seorang pimpinan sudah melaksanakan tugas kepemimpinannya dalam berbagi kepemimpinan dengan wakil kepala sekolah.

4) $\mathrm{BP} / \mathrm{BK}$

Fungsi BP itu pada dasarnya memberikan bimbingan kepada siswa, disamping ada tugas-tugas lain yang berkaitan dengan BP. Hasil observasi dokumen di ruang $\mathrm{Bp}$ penulis menemukan sruktur organisasi bimbingan konseling, Mekanisme kerja bimbingan dan konseling, tata tertib siswa, serta kridit poin siswa yang tertempel di dinding ruang BP. Terdapat pula programprogram BP, buku tamu, catatan buku kasus, arsip undangan pemanggilan wali murid, data konseling individu.

\section{5) Kepala Urusan}

Kepala urusan yang ada di SMP Negeri 21 Purworejo ada empat kepala urusan. Kepala-kepala urusan tersebut bekerja membantu kepala sekolah sesuai dengan bidangnya masing-masing. 
6) Wali Kelas

Tugas wali kelas dapat diketahui: a) mengelola kelas yang menjadi tanggung jawabnya, b) berinteraksi dengan orang tua/wali peserta didik, c) Menyelenggarakan administrasi kelas, d) menyusun dan melaporkan kemajuan belajar peserta didik, e) Membuat catatan khusus tentang peserta didik, f) mencatat mutase peserta didik, g) mengisi dan membagi buku laporan penilaian hasil belajar, h) melaksanakan tugas lainnya yang berkaitan dengan wali kelas, i) menyusun laporan tugas sebagai wali kelas kepada kepala sekolah.

7) Guru Mata Pelajaran

Dalam menjalankan tugas-tugasnya guru harus pakai planning atau rencana. Tugas pokok guru secara umun: a) Membuat program pengajaran, 2) melaksanakan kegiatan pembelajaran, c) meningkatkan penguasaan materi pelajaran yang menjadi tanggungjawabnya, d) memilih metode yang tepat untuk menyampaikan materi, e) melaksanakan $\mathrm{KBM}$, f) menganalisa hasil evaluasi, g) mengadakan pemeriksaan, pemeliharaan, dan pengawasan ketertiban, keamanan, kebersihan, keindahan, dan kekeluargaan, h) melaksanakan kegiatan penilaian, i) meneliti daftar hadir siswa sebelum memulai pelajaran, j) membuat dan menyusun lembar kerja, k) membuat catatan tentang kemajuan hasil belajar masing-masing siswa, 1) mengikuti perkembangan kurikulum, m) mengumpulkan dan menghitung angka kredit untuk kenaikan pangkat.

Kepala sekolah yang pada hakekatnya merupakan pemimpin pembelajaran, kepala SMP Negeri 21 Purworejo sudah bisa menjadikan guru sebagi pemimpin pembelajaran. Pendelegasian wewenang kepemimpinan dalam pembelajaran sudah dilakukan.

\section{Kepala Sekolah yang Efektif Meningkatkan Pembelajaran dalam Rangka Pengembangan Budaya Mutu di SMP Negeri 21 Purworejo}

Sekolah harus berupaya semaksimal mungkin memberikan layanan yang sebaikbaiknya kepada peserta didik dalam meningkatkan mutu atau prestasi. Sekolah meningkatkan kegiatannya dalam memberikan pelayanan yang bermutu kepada peserta didik. Untuk menaikkan mutu pendidikan kemampuan kepala sekolah dalam mengelola pembelajaran sangat diperlukan sekali. Banyak cara yang digunakan untuk meningkatkan pembelajaran. 


\section{a. Mengevaluasi Program Pembelajaran}

Evaluasi ini dilakukan oleh warga sekolah untuk memantau proses pelaksanaan dan untuk mengevaluasi dari program-program yang telah dilaksanakan. Evaluasi semacam ini sering disebut Evaluasi Diri Sekolah (EDS). Evaluasi dilaksanakan secara jujur dan transparan agar benar-benar dapat mengungkap informasi yang sebenarnya.

Evaluasi program pembelajaran guru bisa juga dievaluasi melaui penelitian tindakan kelas. Karena setelah melakukan PTK guru dapat menemukan masalahmasalah pembelajaran untuk selanjutnya guru melakukan perbaikan untuk meningkatkan pembelajaran di masa yang akan datang. Pembelajaran supaya menjadi lebih baik dan efekti, tapi di SMP Negeri 21 Purworejo masih jarang guru yang mau melakukan PTK.

\section{b. Strategi Kepala Sekolah dalam Meningkatkan Pembelajaran}

Strategi-strategi yang digunakan meliputi:

1) Motivasi

Motivasi merupakan salah satu aspek utama bagi keberhasilan dalam belajar. Oleh karena itu, semua staf di sekolah dan juga murit senantiasa dimotivasi. Komunikasi berfungsi sebagai motivasi. Dengan komunikasi yang baik dan efektif, kepala sekolah dapat meningkatkan semangat, antusiasisme, dan optimisme peserta didik. Motivasi atau dukungan dari berbagai pihak baik itu dari kepala sekolah, guru, orang tua maupun dari dalam pribadi siswa sendiri

2) Les (tambahan jam pelajaran) dan Drill Soal-soal

Untuk melaksanakan les dibentuk tim les yaitu guru-guru yang mengajar empat mata pelajaran yang diujikan dalam ujian nasional seperti mata pelajaran bahasa Indonesia, Bahasa Inggris, Matematika serta IPA. Setiap guru yang terlibat les diberi imbalan berupa uang, sumber dana diamblikan dari dana komite sekolah. Orang tua siswa melalui wadah komite sekolah telah memberi kontribusi kepada para guru les.

3) Memberikan penghargaan (rewards) kepada guru, staf dan murid yang berprestasi

Penghargaan ini sangat penting untuk meningkatkan profesionalisme tenaga kependidikan, dan kepada para siswa dapat merangsang untuk meningkatkan 
prestasi pembelajaran. Melalui penghargaan para tenaga kependidikan dapat dirangsang untuk meningkatkan profesionalisme kerjanya secara positif dan produktif.

Cara kepala sekolah untuk meningkatkan profesionalisme dan meningkatkan hasil prestasi belajar pada anak, kepala sekolah memberikannya dalam bentuk penghargaan/rewards.

4) Monitor Terhadap Kemajuan Siswa

Monitoring akan meningkatkan kualitas atau mutu pembelajaran anak.

5) Meningkatkan Sarana Prasarana

Sarana dan prasarana yang ada di SMP Negeri 21 sudah sesuai dan mencukupi.

\section{c. Mendorong Warga Sekolah untuk Berkolaborasi dalam Pembelajaran}

Kepala Sekolah selalu mendorong para guru untuk saling kerja sama, bertukar pikiran, berbagi ilmu dalam mengatasi masalah pembelajaran. Para guru dalam bekerja saling bekerja sama, antara yang satu dengan yang lain.

Kepala sekolah sebagai seorang pimpinan sudah mendorong, membimbing para tenaga pendidikan dan siswa untuk melakukan kerja sama dalam menghadapi tugas-tugas yang berkaitan dengan pembelajaran.

\section{d. Pembelajaran Dilakukan dengan Menggunakan Metode yang Interaktif, Inspiratif, dan Menyenangkan}

Pelaksanaan pembelajaran para guru di SMP Negeri 21 Purworejo sebagian besar telah melaksanakan pembelajaran interaktif, inspiratif, dan menyenangkan. Dengan pembelajaran tersebut sebagian besar guru sudah mengajar dengan baik suasana kelas hidup, pembelajarannya menyenangkan karena berhasil mengaktifkan murid dan guru hanya sebagai fasilitator saja, mereka juga bisa membangun motivasi terhadap anak yang diharapkan bisa menginspirasi anak. Dalam pembelajaran mereka juga memanfaatkan alat peraga.

Kepala sekolah sudah berhasil mengkoordinir sebagian besar guru untuk melakukan pembelajaran dengan menggunakan metode pembelajaran yang Interaktif, inspiratif, menyenangkan, kreatif, menantang. Dengan pembelajaran tersebut mutu siswa SMP Negeri 21 Purworejo dari tahun ke tahun mutu siswa mengalami peningkatan. 


\section{e. Menggunaka Teknik Supervisi}

Kegiatan utama pendidikan di sekolah dalam rangka mewujudkan tujuannya adalah kegiatan pembelajaran, sehingga seluruh aktivitas organisasi sekolah bermuara pada pencapaian efisiensi dan efektivitas pembelajaran. Dalam perannya sebagai supervisor, tugas utama Tatan Sutrisna adalah menyusun program supervisi, dilanjutkan dengan pelaksanaan supervisi, dan diakhiri dengan program tindak lanjut supervisi.

Terhadap kinerja guru Tatan Sutrisna dengan melakukan supervisi kunjungan kelas. Kunjungan kelas dapat digunakan oleh kepala sekolah sebagai salah satu teknik untuk mengamati kegiatan pembelajaran secara langsung. Hasil supervisi dijadikan sebagai dasar kegiatan tindak lanjut. Teknik yang diguakan adalah merefleksikan hasil supervisi dengan guru sasaran supervisi.

Proses pembelajaran di sekolah oleh Tatan Sutrisna disupervisi dan dievaluasi mulai dari tahap perencanaan, pelaksanaan, dan penilaian hasil pembelajaran, termasuk program tindak lanjut. Teknik supervisi digunakan sebagai control/pengawasan terhadap tugas guru.

\section{f. Mendorong Guru dan Staf untuk Meningkatkan Profesinya}

Kepala sekolah menyusun program supervise, dilanjutkan dengan pelaksanaan supervisi, dan diakhiri dengan program tindak lanjut supervisi. Hasil supervisi dijadikan sebagai dasar kegiatan tindak lanjut. Teknik yang digunakan adalah merefleksikan hasil supervisi dengan guru sasaran supervisi.

Proses pembelajaran di sekolah disupervisi dan dievaluasi mulai dari tahap perencanaan, pelaksanaan, dan penilaian hasil pembelajaran termasuk program tindak lanjut. untuk meningkatkan pembelajaran kepala sekolah menggunakan teknik supervisi sebagai kontrol/pengawasan terhadap tugas guru.

5. Kepala Sekolah yang Efektif Mengelola Sumber Daya Manusia, Data, dan Proses untuk Membantu Perbaikan Sekolah dalam Rangka Pengembangan Budaya Mutu di SMP Negeri 21 Purworejo

\section{a. Kemampuan Mengelola Sumber Daya Manusia}

Dalam mengelola sumber daya manusia kepala sekolah telah bertindak dengan tepat dan akurat karena telah memilih dan menempatkan orang baik itu guru maupun staf yang lain bekerja sesuai dengan keahliannya, para guru mengajar sesuai dengan 
ijazahnya. Di samping itu, kepala sekolah mampu memberikan dukungannya kepada orang-orang dalam sekolah, untuk mengembangkan profesinya melalui kegitan diklat, seminar, workshop, penataran, MGMP seta memberikan kesempatan luas kepada para guru atau staf untuk melanjutkan pendidikan ke jenjang sekolah yang lebih tinggi. Dalam memberikan kesempatan untuk pengembangan profesinya ini kepala sekolah bekerja sama dengan instansi yang ada di tingkat kabupaten maupun instansi yang ada di tingkat propinsi serta lembaga-lembaga swasta yang ada, dan sekolah menfasiltasinya dengan memberikan surat tugas dan transpot yang besarnya sesuai dengan yang sudah di atur dalam aturan sekolah.

Kepala sekolah mengenal serta memanfaatkan kekuatan atau potensi yang dimiliki oleh para guru, seperti guru-guru yang memiliki potensi dalam bidang olah raga bola volley, pencak silat, pandai memainkan music Drum Band, pandai dalam main music dan menyanyi diberdayakan atau dimanfaatkan untuk menjadi guru ekstra kurikuler, walaupun secara ijazah sekolah keahlian mereka tidak ada hubungannya sama sekali. Sekolah diberi keuntungan mendapatkan guru ekstra tidak harus susah-susah mencari dari luar tapi sudah tersedia di sekolah, dan secara pembiayaan lebih efisien, karena kalau memanggil guru dari luar biayanya lebih mahal.

Dalam mengelola orang, Tatan Sutrisna bersikap sangat hati-hati sekali, tidak gegabah, tidak semena-mena, ramah, banyak memberikan teladan, sehingga membuat orang yang ada disekelilingnya menjadi nyaman. Staf-sataf yang ada di buat kerasan, apalagi mereka banyak memberikan kekuatan untuk menunjang terwujudnya mutu sekolah. Jadi bagaimana caranya kepala sekolah mampu mempertahankan guru-guru berkualitas terbaiknya agar tidak minta mutase atau yang honorer tidak mengundurkan diri. Kepala sekolah yang sukses memegang peranan positif dalam mempertahankan staf yang berkualitas. Pengunduran diri guru juga berarti hilangnya asset untuk mewujudkan mutu sekolahnya.

\section{b. Kemampuan Mengelola Data}

Dalam mengelola data-data yang ada di sekolah, Tatan Sutrisna telah berusaha semaksimal mungkin untuk terwujudnya data-data sekolah yang terkelola dengan baik. Untuk memutuskan suatu masalah kepala sekolah tidak bertindak gegabah, melainkan telah memanfaatkan data dengan sebaik-baiknya sebagai rujukan dalam 
membuat keputusan. Data di simpan dengan sebaik-baiknya supaya tidak rusak atau hilang. Untuk itu data-data yang berwujud kertas dibenahi, disimpan, ditata denga rapi supaya gampang di cari dan di tempatkan di almari yang terkunci. Untuk datadata yang tersimpan di dalam kompiuter, kepala sekolah menekankan supaya data terbut di copy dalam flesdisk, serta disimpan juga dalam bentuk prin out, maka kalau sewaktu-waktu kompiuter mengalami kerusakan, flesdis hilang, sekolah masih punya arsip dalam bentuk prin out.

Kepala sekolah memanfaatkan data untuk penyellidikan kolaboratif antara guru, wali kelas, BP, orag tua dalam membuat keputusan-keputusan sekolah. Berdasarkan temuan hasil penelitian bahwa untuk memutuskan anak itu lulus atau tidak lulus, naik atau tidak naik, maka perlu cek n ricek antara data yang dimiliki oleh guru bidang study, wali kelas maupun BP. Sehingga ketika anak itu diputuskan tidak lulus atau tidak naik apabila ada komplai dari orang tua, maka untuk menjawab pertanyaan-pertanyaan tersebut menjawabnya dengan menunjukkan data-data yang valid dan bisa dipertanggung jawabkan.

\section{c. Kemampuan Mengelola Proses}

Dalam mengelola proses Nampak bagaimana Tatan Sutrisna di dalam merencanakan, melaksanakan serta memonitoring. Proses dikatakan bermutu tinggi apabila pengkoordinasian dan penyerasian serta pemanduan input sekolah (guru, siswa, kurikulum, biaya, fasilitas, dan sebagainya) dilakukan secara harmonis, sehingga mampu menciptakan situasi pembelajaran yang menyenangkan, mampu mendorong motivasi dan minat belajar, dan benar-benar mampu memberdayakan siswa. Kata memberdayakan mengandung arti bahwa siswa tidak sekedar menguasai pengetahuan yang diajarkan gurunya, akan tetapi pengetahuan tersebut juga telah menjadi muatan nurani siswa, dihayati, diamalkan dalam kehidupan sehari-hari, dan yang lebih penting lagi siswa tersebut mampu belajar secara terus-menerus (mampu mengembangkan dirinya).

Di dalam proses penerimaan siswa baru tatan sutrisna menggunakan langkah yang baik. Dalam temuan hasil penelitian diperoleh data bahwa kepala sekolah untuk menjaring siswa baru menggunakan sistim seleksi berdasarkan NEM yang masuk. Animo masyarakat cukup banyak yang ingin masuk ke SMP Negeri 21 Purworejo sementara daya tampung sekolah sangat terbatas yaitu hanya 5 rombel yang mana 
bahwa kuota yang tersedia hanya seratus enam puluh orang. Dengan banyaknya yang mendaftar maka kesempatan besar untuk mendapatkan siswa dengan memiliki nem yang baik. Mendapatkan input yang baik, dikelola secara baik, maka akan didapatkan output yang baik.

Dalam proses penerimaan guru atau pegawai yang baru, lowongan pegawai diumumkan secara terbuka kepada umum, disosialisasikan kepada warga sekolah untuk disebarkan kepada khalayak banyak. Disamping itu juga diumumkan melalui grup-grup Whatsapp (memanfaatkan teknologi yang telah ada). Dengan demikian diharapkan akan semakin banyak yang thud an semakin banyak yang mendaftar. Dengan semakin banyak yang mendaftar maka kemungkinan besar untuk bisa memilih calon guru atau calon pegwai yang berkualitas yang bisa memberikan kontribusi untuk kemajuan SMP Negeri 21 Purworejo mencapai dalam rangka mewujudkan mutu sekolah. Di samping menggunakan persyaratan tertentu penyeleksian pegawai yang baru juga dengan menggunakan wawancara. Untuk mengisi kekosongan guru atau prgawai kepala sekolah meminta pendapat dari pawa wakil kepala sekolah, guru maupun karyawan. Walaupun sebenarnya sudah bisa memilih berdasarkan kriteria yang diinginkan alangkah baiknya kalau mendapatkan masukan dari orang banyak. Dengan pegawai atau guru baru yang berkualits akan semakin memperkuat mutu sekolah karena itu para guru atau pegawai baru selalu dimonitor, dibimbing, diarahkan untuk betul-betul siap menjadi seorang pegawai yang berkualitas. Dengan terus mendapatkan bimbingan akan cepet menyesuaikan diri dengan sekolah.

\section{KESIMPULAN}

Berdasarkan hasil penelitian dan pembahasan dapat diambil simpulan sebagai berikut:

1. Kepala Sekolah yang Efektif Membentuk Visi dalam Rangka Pengembangan Budaya Mutu di SMP Negeri 21 Purworejo

Dalam mewujudkan pengembangan budaya mutu di SMPN 21 Purworejo, kepala sekolah mampu menciptakan, menjabarkan, serta memelihara visi yang kuat, yang dapat dilihat dari penanaman nilai-nilai atau budaya sekolah sebagai berikut: budaya bersih, budaya baca, budaya disiplin, budaya jujur, budaya religius, serta budaya berprestasi. 
Untuk menciptakan suasana pembelajaran yang kondusif, Kepala Sekolah SMP Negeri 21 Purworejo dengan menegakkan tata tertib sekolah, baik itu tata tertib siswa, maupun tata tertib guru karyawan. Kepada para siswa yang melakukan pelanggaran-pelanggaran diberi sangsi yang mendidik.

2. Kepala Sekolah yang Efektif menciptakan Iklim Ramah terhadap Pendidikan dalam Rangka Pengembangan Budaya Mutu di SMP Negeri 21 Purworejo

Kepala SMPN 21 Purworejo sudah bisa menanamkan nilai-nilai atau budaya ramah terhadap warga sekolah. Ini dibuktikan adanya iklim organisasi yang terbangun di SMPN 21 Purworejo baik, baik secara internal maupun eksternal. Secara internal ditunjukkan oleh adanya hubungan baik antar warga sekolah. Langkah-langkah yang dilakukan dengan cara: (a) Menyediakan fasilitas sekolah yang Aman dan nyaman Serta Ramah Terhadap Lingkungan, (b) Menciptakan Iklim yang Ramah Bagi Peserta Didik dan Staf. (c) Secara eksternal berhasil menciptakan iklim ramah yang melampaui batas tembok sekolah, ditunjukkan melalui jalinan hubungan baik dengan orang tua siswa, dengan komite sekolah, dan lain sebagainya. Dengan terbangunnya hubungan harmonis/ramah, baik secara internal maupun eksternal yang ditunjukkan oleh kerja sama, saling menghargai, dan saling membantu, mutu layanan akan semakin baik, maka memungkinkan ilklim belajar menjadi sejuk dan tenang, sehingga akan berdampak pada motivasi belajar siswa, pada akhirnya akan tercapainya kualitas atau mutu pendidikan di sekolah.

3. Kepala Sekolah yang Efektif Membina Kepemimpinan pada Orang Lain dalam Rangka Pengembangan Budaya Mutu di SMP Negeri 21 Purworejo

Dengan adanya pelimpahan wewenang, inisiatif dan rasa tanggung jawab para staf dapat lebih terdorong untuk melakukan pekerjaan dengan lebih baik yang pada gilirannya dapat menghasilkan kinerja yang bermutu. Kepala sekolah berupaya mengoptimalkan peran seluruh sumber daya sekolah yang ada yaitu dengan cara: (a) Kepala sekolah memberi kepercayaan kepada bawahan, (b) Kepala sekolah membangun tim kerja yang efektif, (c) Kepala sekolah mendelegasikan sebagian wewenangnya kepada orang lain. 
4. Kepala Sekolah yang Efektif Meningkatkan Pembelajaran dalam Rangka Pengembangan Budaya Mutu di SMP Negeri 21 Purworejo

Untuk menaikkan mutu pendidikan kemampuan kepala sekolah dalam mengelola pembelajaran sangat diperlukan sekali. Banyak cara yang digunakan Kepala sekolah untuk meningkatkan pembelajaran, yaitu: (a) Mengevaluasi program pembelajaran, (b) Strategi Kepala Sekolah dalam meningkatkan pembelajaran, (c) Mendorong warga sekolah untuk berkolaborasi dalam pembelajaran, (d) Pembelajaran dilakukan dengan menggunakan metode yang interaktif, inspiratif, dan menyenangkan, (e) Menggunakan teknik supervisi, f Mendorong guru untuk meningkatkan profesinya.

5. Kepala Sekolah yang Efektif Mengelol Sumber Daya Manusia, Data, dan Proses untuk Membantu Perbaikan Sekolah dalam Rangka Pengembangan Budaya Mutu di SMP Negeri 21 Purworejo

Untuk pengembangan budaya mutu di SMPN 21 Purworejo kepala sekolah telah menunjukkan kemampuannya mengelola sumber daya manusia yang berkualitas, dengan memasang orang-orang yang tepat sesuai keahliannya, memberikan dukungan kepada staf untuk pengembangan karirnya, memanfaatkan potensi para staf secara maksimal, serta bersikap hati-hati, tidak semena-mena, ramah, dan lebih mengedepankan tauladan. Disamping itu kepala sekolah berhasil mengelola data dengan baik, data dimanfaatkan sebagai rujukan dalam membuat keputusan, penyimpanan data secara tepat, serta pemanfaatan data untuk penyelidikan kolaboratif. Dalam mengelola proses penerimaan peserta didik baru serta pegawai baru terseleksi dengan baik sehingga menghasilkan peserta didik dan pegawai baru yang bermutu, serta melakukan mentoring terhadap pegawai baru untuk dipersiapkan menjadi pegawai yang betul-betul berkualitas kinerjanya.

\section{DAFTAR PUSTAKA}

Aan Komariah \& Cepi Triana. (2008), Visionary Leadership, Menuju Sekolah efektif, Jakarta: Bumi Aksara.

Achmad Sobirin. (2010), Budaya Organisasi, Yogyakarta: STIM YKPN.

Adi Kurnia \& Bambang Qomaruzzaman. (2012). Membangun Budaya Sekolah, Bandung: Remaja Rosdakarya Offset.

Agustinus Hermina. (2014), Pemimpin Pendidikan Di Era Globalisasi, Yogyakarta: Pustaka Pelajar.

Badeni. (2014). Kepemimpinan dan Perilaku Organisasi, Bandung: Alfabeta. 
Dadang Dally. (2010), Balanced Score Card Suatu pendekatan dalam Implementasi Manajemen Berbasis Sekolah, Bandung: Remaja Rosdakarya.

Daryanto. (2015), Supervisi Pembelajaran, Yogyakarta: Gava Media.

Edmonds (1999), Effective School, Oklahoma.

Eliyanto (2018), Manajemen \& Kepemimpinan Pendidikan Islam, Kebumen: Institut Agama Islam Nahdlatul Ulama (IAINU).

Hallinger. (1996), Reassessing The Principal's Role In School Effectiveness: A Review Of Empirical Research, 1980-1995. Educational Administration Quarterly, 32(1), 5-44.

Husaini Usman. (2008), Manajemen, Teori, Praktik, Dan Riset Pendidikan, Jakarta: Sinar Grafika Offset.

Ida Ayu Brahmasari \& Agus Suprayitno. (2008), Pengaruh Motivasi Kerja, Kepemimpinan dan Budaya Organisasi Terhadap Kepuasan Kerja Karyawan Serta Dampaknya Pada Kinerja Perusahaan. Jurnal Manajemen dan Kewirausahaan, Vol.10. No.2, Surabaya: Pascasarjana Universitas 17 Agustus 2008.

Ikbal Barlian. (2013). Manajemen Berbasis Sekolah Menuju Sekolah Berprestasi, Jakarta: Erlangga.

Irham Fahmi. (2014), Manajemen Kepemimpinan Teori \& Aplikasi, Bandung: Alfabeta.

Kartini \& Kartono. (2016), Pemimpin dan Kepemimpinan Apakah Kepemimpinan Abnormal Itu?, Jakarta: Raja Grafindo Persada.

Kaswan. (2019), Kepemimpinan Dampak Dan Warisannya; Praktek Kepemimpinan Untuk Meraih Keunggulan Organisasi Jangka Pendek Dan Jangka Panjang.Jakarta: Bumi Aksara.

Kompri. (2014), Manajemen Sekolah Teori dan Praktik, Bandung: Alfabeta.

(2018), Manajemen dan Kepemimpinan Pondok Pesantren, Jakarta: Prenadamedia Group.

Mardiyah. (2013), Kepemimpinan Kiai Dalam Memelihara Budaya Organisasi, Tlogomas Malang: Aditya Media Publishing.

Mendels, P. (2012). The effective principal. Journal of Staff Development, 33, 1, 54-58.

Michael Quinn Patton. (2006). Metode Evaluasi Kualitatif. Yogyakarta: Pustaka Pelajar.

Mulyasa (2011), Menjadi Kepala Sekolah Profesional, Bandung: Remaja Rosdakarya.

(2015), Manajemen Dan Kepemimpinan Kepala Sekolah,Jakarta: Bumi Aksara.

Mulyono (2008), Manajemen Administrasi \& Organisasi Pendidikan, Jogjakarta: ArRuzz Media.

Nanang Fattah. (2017), Sistem Penjaminan Mutu Pendidikan Dalam Konteks Penerapan MBS, Bandung: Remaja Rosdakarya.

Nurkolis (2006), Manajemen Berbasis Sekolah Teori, Model dan Aplikasi, Jakarta: Grasindo. 
Paine Lyn.S. (1994), Managing For Organizational Integrity, Harvard Busines Review.

Edward Sallis. (2012), Total Quality Management In Education, Terjemah Ahmad Ali Riadi \& Fahrurozi, Yogyakarta: Ircisod.

Spiro, J.D. (2015). Effective principals in action. Principal's Research Review, 10, 1, 1 6.

Stephen P. Robbins. (2003), Organizational Behavior. San Diego State University: Person Education International.

Stolp S. (1994), Leadership For School Culture, Eric Digest: Number 91.

Sudarwan Danim. (2015), Visi Baru Manajemen Sekolah Dari Unit Birokrasi ke Lembaga Akademik, Jakarta: Bumi Aksara.

Sugiyono. (2009). Metode Penelitian Pendidikan. Bandung: Alfabeta.

Wuradji. (2008), The Educational Leadership, Kepemimpinan Transformasional, Yogyakarta: Gama Media. 